\title{
Active and adaptive sustainable environments for children's outdoor space
}

\author{
M. Winkler \& S. Macaulay \\ Department of Architectural Science, Faculty of Engineering, \\ Architecture and Science, Ryerson University, Canada
}

\begin{abstract}
The slow and often cantankerous momentum of transforming children's school grounds and public open space areas in to stimulating environments for learning has grown steadily over the past decades. In North American, Europe and Asia partnerships have been formed between school communities, school boards, politicians, big business, and NGO's (non-government organization), to develop, design, and convert often bleak landscapes in to rich and diverse natural environments with plentiful curriculum, play and environmental connections. This process primarily focuses on the initial and immediate physical outcome of the capital venture. There is generally limited consideration for the long term sustainability and integrity of the site. Multi-disciplinary professionals often neglect understanding that a completed landscaped site is dynamic, not static, in terms of natural processes, physical forms, social needs and practical functions. Issues include the selection of natural and manufactured materials for short and long term durability, disposability and sensitivity to the environment; visual enjoyment and inherent appreciation of material weathering; foreseen and unforeseen maintenance costs. These matters need to be addressed upfront in the design process and not be relegated as an afterthought. Only then can we attempt to ensure that material selection, installation techniques and monitoring of the site can effectively and economically support an active and adaptive sustainable environment for children's current and future outdoor spaces.

Keywords: design, natural, open space, children, plant materials, sustainability, environment, communities, school grounds, hard landscape materials.
\end{abstract}

\section{Introduction}

The design process for the creation of children's outdoor urban space has evolved over many decades. In the 1950's North American school yards and 
children's designed open spaces consisted primarily of patchy grass areas, black asphalt paving and cold steel playground equipment. In the 1970's New York City's landscape architect M. Paul Friedberg [1] and other professionals introduced a new generation of children to modern play areas made of tactile wooden structures and rubber tires often built above the softer and more pliable wood chipped surfaces. By the 1980's brightly coloured, complex plastic structures dotted children's landscapes. Through all these decades' active physical play and socialization remained the primary focus of children's outdoor designed spaces.

\section{Shift in paradigms}

In 1980 The Brundtland Report, commissioned by the United Nations entitle, "Our Common Future. World Commission on Environment and Development", was released to the public. The report spoke about responsible growth in first and third world countries and coined the term "Sustainable Development" [2]. It was also during this period that books such as architect Michael Hough's, "City Form and Natural Processes", brought the concept of appreciating and understanding one's local "Sense of Place". [3] New programs and courses were introduced to universities such as environmental studies, environmental engineering, landscape ecology, naturalization of highway corridors, native planting design. This information was disseminated to many, as well as those in charge of and interested in children's open space. The movement towards developing play spaces that directly related to the site's bioregion or natural environment had begun.

\subsection{Transformation of ideas}

In 1990's school grounds and open space design began to embrace the idea of local nature as the outdoor classroom. Designers, educators and communities began developing principles toward the transformation of school grounds [4] and public open spaces as part of an active holistic system. New designs began to emerge encouraging a strong sense of place and understanding that diverse learning environments need to be rich in curriculum, environmental, health and safety issues and their intertwining connections. Now, like never before master plans for new, rejuvenated and restored sites are increasingly and consciously including areas high in biodiversity of plant materials and wildlife. With this increasing commitment to the environment, comes a need to revisit phases of the design process. Designing, building, managing and maintaining an area rich in biodiversity is more complex. Sites are no longer composed of a monoculture landscape filled with asphalt, grass and ornamental trees. A comparison can be made in architecture when buildings have a single function, for instance a storage warehouse versus a science centre. The former requires arguably less understanding of material selection, application and user need. While a science centre is much richer and diverse in its functions, forms and user activities. 


\subsection{1 "How to" books}

User friendly books, pamphlets, papers, conferences, workshops and lectures discuss the need for environmentally friendly school grounds promoting the use of native planting and naturalization [5], understanding of ecozones and embracing the importance of designing for shade [6]. "How to", literature for organizing and recruiting the community, [7] seeking funding and providing the necessary tools to guide the design process continue to flourish and be embraced by designers and communities.

2.1.1.1 Beyond the ribbon cutting ceremonies Initiatives used to generate funds for these capital projects require enormous effort, particularly on the part of the community. The excitement of the inclusive design process and resulting new environment is generally heralded by all. However, after the ribbon cutting ceremony, the on going support of the site is often over looked and generates little interest by the initial partnerships.

\section{Greater responsibility}

Along with the new paradigm shift comes a greater responsibility on the part of designers to be more actively engaged in understanding the benefits of sustainability both pre and post design selection, installation and maintenance. In Ontario, services of Landscape Architects are demarcated into categories. Categories include; consulting \& advising, pre-conceptual planning and predesign, design \& contract documents, services before $\&$ during construction and responsibilities of Landscape Architect and client (payment \& copyright) [8] Within these guidelines there are few clearly defined guidelines for long term maintenance for an active and adaptive landscape design.

Sustainable designed environments require forward thinking designers who are actively mindful and aware of the site and users present and long term needs. The designer should evaluate the project's layout, material selection and installation applications in terms of local sourcing of materials, life cycle assessment of materials, sustainable installation techniques, costs, aesthetics and user requirements of site. Life cycle assessment for buildings and construction are available for the architectural and engineering profession and industry with LCA software programs such as Environment Australia's [9] and Athena's Sustainable Materials Institute in Ottawa, Canada [10]. Software of this kind is presently unavailable to outdoor, landscape sites. [11] It is time for monitoring and maintenance plans and budgets, which are often ignored, be placed up front and centre in the design process and not relegated as an afterthought.

\subsection{Monitoring and managing change}

A young school ground and children's open space landscape design is not unlike the young family that uses it. The needs of the whole family and each individual member evolve over time. The excitement of forming a family is quickly tempered by the responsibilities and necessary changes required for this new life 
style. There is also tremendous excitement when designing a school ground and children's open space. The family in this context consists of children, caregivers, staff, volunteers, community, policy makers, designers and politicians. Over time, demands on and responsibilities toward the site change, yet the basic need for a safe, healthy and sustainable environment remains core. Adaptive sustainable environments monitor and manage predictable and unforeseen changes that occur post construction and beyond. This is achieved through developing a workable and adaptable monitoring and managing maintenance plan and budget.

\subsubsection{Abiotic paving materials and biotic materials}

School grounds and children's open space are generally composed of commonly used paving and vegetative materials. Each material is both multi-purpose in function, aesthetics and physical form. Understanding the components of these materials and their design connections assist in the promotion of sustainable design.

\begin{tabular}{|l|l|}
\hline Paving Materials /Abiotic & Vegetation Groupings/Biotic \\
\hline Asphalt Interlocking & Trees \\
\hline $\begin{array}{l}\text { Concrete Pavers, } \\
\text { Concrete Pavers (ICP) }\end{array}$ & \\
\hline Natural Stone Pavers & Vines \\
\hline Limestone Screening/Aggregates & Perennials \\
\hline Pea Gravel & Grasses \\
\hline Wood Boardwalk & Bulbs and Tubers \\
\hline Wood Chips & Annuals \\
\hline Sand & Vegetable/Herbs \\
\hline Poured in Place Concrete & Grass \\
\hline Brick & \\
\hline Rubber & \\
\hline
\end{tabular}

Figure 1: Commonly used paving materials and vegetation groupings.

\section{Active and sustainable design solutions}

The following information contains examples of typical design problems that can be resolved prior to completion of design work and suggestions of adaptable landscape applications.

\subsection{Design problem 1: outdoor seating}

Timber logs are often used in school grounds and open space landscapes for seating. Logs are usually inexpensive to attain or donated to projects. Transportation to the site is easily accomplished. When numerous logs are arranged in a circle it is referred to as a "Council Ring". This term was originally coined in the first half of 1900's by Danish landscape architect Jens Jenson. In 
the school yards, council rings are wonderful multi purpose seating areas, servings as outdoor lunchrooms, outdoor classroom and play areas. Over time these logs begin to decompose and decay, resulting in a weaken structure along with growth of unwanted mushrooms. It will be the principal's responsibility to request removal of these logs by the school board's maintenance staff. The cost of removal and disposal of the logs can be high and generally comes from the principal's own school budget. In essence, six free wood logs, could cost a school $\$ 600$ to remove and dispose from the grounds [12].

Landscape Design Intent

\begin{tabular}{|c|c|c|}
\hline Design Outcome & $\begin{array}{c}\text { Adaptive Management } \\
\text { Solutions }\end{array}$ & Graphic Sample \\
$\begin{array}{c}\text { Wooden logs weather } \\
\text { and deteriorate, } \\
\text { requiring removal } \\
\begin{array}{c}\text { using scare monetary } \\
\text { budgets. }\end{array}\end{array}$ & $\begin{array}{c}\text { Selection of quarried } \\
\text { stones or large rocks } \\
\text { will provide similar } \\
\text { function to site. } \\
\text { Material has longer life } \\
\text { cycle. }\end{array}$ & Decomposing wood \\
\hline
\end{tabular}

Figure 2: Landscape design intent: outdoors seating space [13].

Active and Adaptive Sustainable Design Solution: Use small boulders from nearby excavated residential or commercial construction sites. Contact local developers who access boulders on a regular basis. Boulders are often donated to school projects and have a long life cycle. Another material with long life cycle is ledge rock. Ledge rock is pre-cut and pre-sized for site specific design intent. This hard landscape material can be purchased at local quarries.

\subsection{Design problem 2: staking young caliper trees}

Small caliper trees are often given to school grounds through grants and community partnerships. These young trees and whips require tender care if they are not only to survive but thrive. Small caliper trees and children can be a receipt for disaster unless supportive maintenance and monitoring safe guards are installed. For a small caliper trees, proper mechanical staking, guying, or bracing is required for support against harsh winds, snow deposition, animals and people [14].

Active and Adaptive Sustainable Design Solution: There are a variety of biodegradable staking materials and suitable techniques to select from. Tree staking can create tripping hazards, so each area must be assessed on an individual basis. Tree staking requires proper identification in both design specifications and detail drawings. The first two growth years are the most critical for the plant's survival. Stakes are typically removed after two years, but this policy should be re-evaluated on school grounds. 


\begin{tabular}{|c|c|}
\hline Design Outcome & $\begin{array}{c}\text { Adaptive Management } \\
\text { Solutions }\end{array}$ \\
\hline $\begin{array}{c}\text { Trees often require } \\
\text { staking at new sites. If } \\
\text { the staking is not } \\
\text { monitored, the bark } \\
\text { monitored for height, } \\
\text { caliper, habit and } \\
\text { general well being. } \\
\text { can be restricted and } \\
\text { girdling can begin in } \\
\text { just one year. Girdling } \\
\text { can restrict proper } \\
\text { length and location will } \\
\text { plant growth and } \\
\text { cheate a haven for }\end{array}$ & $\begin{array}{c}\text { continuous plant } \\
\text { growth. }\end{array}$ \\
disease and decay. & Choking of Tree Trunk \\
\hline
\end{tabular}

Figure 3: Landscape design intent: planting small caliper trees [15].

\begin{tabular}{|c|c|c|}
\hline Design Outcome & $\begin{array}{c}\text { Adaptive Management } \\
\text { Solutions }\end{array}$ & Graphic Sample \\
\hline $\begin{array}{c}\text { Natural stone has } \\
\text { advantages and } \\
\text { disadvantages } \\
\text { depending on material } \\
\text { selection, site stresses } \\
\text { and location. [10] }\end{array}$ & $\begin{array}{c}\text { Place natural stone on } \\
\text { sharply pointed and } \\
\text { agell compacted } \\
\text { edges provide greater } \\
\text { opening between } \\
\text { aggregates allowing for } \\
\text { more water infiltration. }\end{array}$ & $\begin{array}{c}\text { Tripping } \\
\text { Hazards/Screening } \\
\text { Material }\end{array}$ \\
\hline
\end{tabular}

Figure 4: Landscape design intent: material selection for paths [16].

\subsection{Design problem 3: material selection for path}

Natural stone has a long life cycle on pathways. Natural stones is found in a beautiful range of colours and can be purchased from local supplier either square cut or irregular shape. Hard landscape materials such as shale weather and flake over a relatively short time period. Others such as Owen Sound are much stronger. In cold climates, the natural freezing and thawing action cause the stone to lift and shift from the installed location. This creates serious tripping hazards for individuals, particularly individuals with physical handicaps.

Limestone screenings is often used for pathways due to low cost, aesthetically pleasing colour, ease of installation and sourcing. Limestone screening is a powdery like sustain when dry. The small partials collect on the outer soles of shoes in school yards. This often creates a maintenance problem as children reenter the school building after recess and lunch. The small and numerous limestone screening footprints of students can be seen up and down the hallways and classrooms of the school building. 
Heavy rains turn this soft powdery material into compacted areas where water is prevented from infiltrating back into the groundwater and puddles appear.

Active and Adaptive Sustainable Design Solution: Removing excessive amounts of paving material will assist in returning more water back to the subgrade [17]. When walking paths are required, install 3" $(7.6 \mathrm{~cm})-4$ " $(10 \mathrm{~cm})$ of well compact angular aggregates. Recycled plastic grids are also commercially available to stabilize aggregates. [18] If plant roots are near the path, reduce the amount of excavation to a minimum. Examine slope and drainage pattern of surrounding area and place mulch bark.

\subsection{Design problem 4: autumn foliage}

Large open space areas are often bordered with large deciduous tress. Trees are randomly located in the open space areas. In the autumn, leaves drop and are collected with both hand held leaf blowing machines and leaf blowing service vehicles. They are neatly piled up high, lifted by a bobcat into a dump truck and transported off site. There is a tremendous waste of energy and people power to remove this natural material.

\begin{tabular}{|c|c|c|}
\hline Design Outcome & $\begin{array}{c}\text { Adaptive Management } \\
\text { Solutions }\end{array}$ & Graphic Sample \\
\hline $\begin{array}{l}\text { Autumn foliage is } \\
\text { usually removed from } \\
\text { the site with costly } \\
\text { manpower and large } \\
\text { consumption of energy. } \\
\text { Land is compacted and } \\
\text { oxygen is reduced } \\
\text { through the use of } \\
\text { heavy equipment. }\end{array}$ & $\begin{array}{l}\text { Lawn mowers over } \\
\text { fallen leaves provide } \\
\text { natural mulch for the } \\
\text { grass. }\end{array}$ & \\
\hline
\end{tabular}

Figure 5: $\quad$ Landscape design intent: autumn foliage [19].

Active and Adaptive Sustainable Design Solution: A sustainable method would be to mow the leaves, (as you would grass) and place this new mulch on planting areas through out the site. This mulch would create a natural blanket for perennials and grasses during the upcoming winter season.

\subsection{Design problem 5: aboveground concrete planters}

The average life span of a tree in an above ground container is seven years. Plant roots have extremely limited space to move and grow in this unnatural and hostile environment. Maintenance and monitoring of plant growth is rarely done and poorly executed. Actual watering of above grade containers is almost negligible thereby threatening survival [20] [21].

Active and Adaptive Sustainable Design Solution: Plant trees in large above ground container islands. This allows for shared root space and more soil 
volume. Larger trees have better long term survival in this environment. Although PVC pipes are not recyclable, they can assist in plant survival. Placed in the aboveground container, they collect rainwater and direct it to the root system.

\begin{tabular}{|l|l|}
\hline \multicolumn{1}{|c|}{ Design Outcome } & $\begin{array}{c}\text { Adaptive Management } \\
\text { Solutions }\end{array}$ \\
\hline $\begin{array}{l}\text { In cold climates, the } \\
\text { freezing and thawing } \\
\text { action of the soil and } \\
\text { root ball places } \\
\text { pressure on the } \\
\text { aboveground planters, } \\
\text { aboveground planters, } \\
\text { especially in cold } \\
\text { climates. The entire } \\
\text { plastic container for root } \\
\text { ball should be removed } \\
\text { from tree. }\end{array}$
\end{tabular}

Figure 6: Landscape design intent: aboveground concrete planters [22].

\section{Toward active and adaptable design}

Designers need to take a more active role in obtaining relevant information towards the pursuit of sustainability in children's open spaces. There are many organizations such as Interlocking Concrete Paving Institute, (ICPI), American Nursery Landscape Association (ANLA) and Canadian Nursery Landscape Association (CNLA) which offer the latest scientific research information on these products. Equally important is sustaining a healthy site through monitoring, maintenance and recording of landscape components. Review of the original design in terms of adequate layout, solid technical applications, material life cycles, existing functions, safety, natural processes and human use are to be noted. Based on this information monies can be allocated to adapted the site for current and future needs and/or requirements.

\subsection{Planning for maintenance in the design}

It is time to insist on a proactive approach to the funding of children's open space designs. Abiotic and biotic material selection and intended usage require evaluation during the design decision making process and post construction review. Allocation of money for monitoring, managing and maintaining the site needs to be incorporated into the capital budget. This will assist in ensuring children's school grounds and open space areas will not return to the monoculture of grass and asphalt.

\section{Conclusion}

Sustainable and diverse open space children area's that recognize and integrate existing systems and contextual areas can be a long term a source of enjoyment 
and enrichment for children and as they make the journey through the education system.

At the same time, it would be incorrect to believe these sites will remain permanent fixtures on the land. Natural weathering, decay of materials, cultural shifts, economic realities, and time itself will eventually have the greatest impact on a site. Because this is inevitable, projects need to be archived for future generations.

\section{References}

[1] Friedberg, M. Paul. Play and Interplay: A Manifesto for New Design in Urban Recreational Environment. London: The Macmillan Company, 1970.

[2] Bruntland, G. (ed.) Our Common Future: World Commission on Environment and Development. Oxford University Press: Oxford. 1987.

[3] Hough, Michael. City Form and Natural Processes. Routledge, London: 1984.

[4] Toronto District School Board, Transforming the Schoolyard, Toronto District School Board, pp. 8-9. 2000.

[5] Aboud S. \& Kock H., A Life Zone Approach to School Yard Naturalization, The Arboretum University of Guelph. pp. 44-55, 1996.

[6] Evergreen, Hand For Nature: A Volunteer Management Handbook, Evergreen: Toronto, pp. 3-19, 2003.

[7] Schaefer, Joseph M. et al., Schoolyard Ecosystems for Northeast Florida, University of Florida, pp 13-23 year.

[8] Ontario Association of Landscape Architects. http://www.oala.on.ca/articles.

[9] Greening the Building Life Cycle. Life Cycle Assessment Tool in Building and construction. http://buildlca.rmit.edu.au/.

[10] Life- Cycle Assessment for Building Buildings: Seeking the Holy Grail. http://www.buildinggreen.com/auth/article.cfm?fileName=110301a.xml.

[11] Athena Sustainable Materials Institute. Personal Phone Call. 2005.

[12] Day, Bruce. Personal Conversation. 09 Oct. 2002. Head of Grounds Maintenance. Toronto District School Board. Toronto, Canada.

[13] Winkler, Alexandra. Illustration 2006.

[14] Harris, R.W., A.T. Leiser, and W.B. Davis. Staking landscape trees. University of California, Davis, Division of Agricultural Sciences Leaflet No. \#2576. pp.13 1978.

[15] Winkler, Alexandra. Illustration 2006.

[16] Winkler, Alexandra. Illustration 2006.

[17] J. William Thompson and Kim Sorvig, Sustainable Landscape Construction A Guide to Green Building Outdoors. Island Press: Calif., pp.73-74. 2000.

[18] J. William Thompson and Kim Sorvig, Sustainable Landscape Construction A Guide to Green Building Outdoors. Island Press: Calif., pp. 187.2000. 
308 Design and Nature III: Comparing Design in Nature with Science and Engineering

[19] Winkler, Alexandra. Illustration 2006.

[20] Peter J. Trowbridge and Nina L. Bassuk, Trees in the Urban Landscape, John Wiley \& Sons: N.J. pp 82-89, 2004.

[21] Gary W. Watson and E.B. Himelick, Planting Trees and Shrubs. International Society of Arboriculture. United Graphics: Il. pp. 43-47. 1997.

[22] Winkler, Alexandra. Illustration 2006. 